\title{
Faecal indicator organisms in the Renoster Spruit system of the Modder-Riet River catchment and implications for human users of the water
}

\author{
M Griesel* and P Jagals \\ Unit for Water and Health, Technikon Free State, Private Bag X20539, Bloemfontein 9300, South Africa
}

\begin{abstract}
The impact of a variety of urban discharges from Bloemfontein on the numbers of microbiological faecal indicator organisms in the water of the Renoster Spruit subcatchment was investigated using E. coli, C. perfringens and somatic coliphages as microbial indicators. The no-observed-adverse-effect-levels for the occurrence of these organisms in water intended for domestic purposes, for full-body contact recreation as well as irrigation of crops that may be eaten raw, were exceeded. The results indicated that the faecally polluted urban runoff, in combination with inadequately treated wastewater effluents, overcame the assimilation capacity of the Renoster Spruit in the immediate vicinity of the city to such an extent that it posed a possible risk of infection to potential water users for considerable distances downstream from the urban area. The high levels of faecal indicators in the Renoster Spruit diminished to such an extent downstream that the receiving Modder River, directly downstream from the confluence with the Renoster Spruit, posed an infection risk for domestic users only but not for recreational users of the water. Water at this point could also be used to irrigate crops eaten raw.
\end{abstract}

\section{Introduction}

Urbanisation generates increasing loads of faecal wastes discharged to natural water resources. In many cases, the extent of pollution causes increases in numbers of faecal indicator organisms to levels which exceed recommended limits for water to be used by humans for purposes such as drinking, recreation, or irrigation of crops eaten raw.

Surface water bodies have a natural capacity to assimilate microbiological contaminants without the quality of water deteriorating beyond its value for ecological sustainability and human use (DWAF, 1995). Usually in urban, peri-urban and adjacent rural areas, surface water bodies receive faecally polluted urban discharges that contain pathogenic micro-organisms in such high numbers that the assimilation capacity of the receiving water body is overcome. This results in an increase in the numbers of faecal indicator organisms in receiving water, which often becomes unfit for domestic purposes, recreation or irrigation of crops eaten raw (Jagals, 2000; Venter et al., 1996).

An impact, in the context of this study, was when faecal pollution, indicated by the numbers of microbiological indicator organisms released with the urban discharges, reached such high levels that the assimilation capacity of the receiving surface water failed to reduce these levels to within acceptable limits (Griesel, 2001; Jagals, 2000; Chapra, 1997). Acceptable limits for the occurrence of faecal indicator organisms in water are recommended in various national and international guidelines and standards such as the South African Water Quality Guidelines (DWAF, 1996a \& b) and the Health Guidelines for the Use of Wastewaterin Agriculture and Aquaculture (WHO, 1989).

* To whom all correspondence should be addressed.

前 051 5073271; fax: 051 5073556; e-mail: mgriesel@tofs.ac.za

Received 19 September 2001; accepted in revised form 11 March 2002.
Significant reduction of microbiological indicator organism levels would imply reduction of the numbers of pathogenic microorganisms in these urban discharges, to levels where their occurrence in the receiving water intended for various human uses, is not expected or observed to have adverse effects on human health. This is referred to as the no-observed-adverse-effect-level (NOAEL) (Kindzierzki and Jackson, 1998; Kolluru et al., 1996).

In the context of this study, domestic water use means water people take from the Renoster Spruit and its tributaries and use at home with limited (generally disinfection with products based on sodium hypochlorite as an active ingredient) or no treatment (Jagals, 2000). Recreational use refers to activities with full bodily contact of the water, such as swimming and water-skiing (DWAF, 1996b). Agricultural use means the irrigation of crops that may be eaten uncooked (Jagals, 2000; Shuval et al., 1997).

This study was done to determine the contribution of urban discharges from Bloemfontein City to numbers of faecal indicator organism numbers in rivers and streams in the Renoster Spruit subcatchment, which lies within the Modder-Riet River catchment in the Free State Province, South Africa.

\section{The study area}

\section{The subcatchment}

The study was conducted in the Renoster, Bloem, and Fontein Spruit systems as well as the sector of the Modder River receiving discharges from these tributaries (Fig. 1). The study area lies within the Middle Modder subcatchment of the Modder-Riet River catchment. The Renoster Spruit (spruit means stream or small river) flows past Bloemfontein and drains into the Modder River. The Renoster Spruit receives a variety of discharges from Bloemfontein City. Some discharges are treated effluents discharged directly from wastewater treatment facilities while other discharges are from surface water runoff from informal settlements on its banks. The Bloem Spruit, a tributary of the Renoster Spruit, runs 


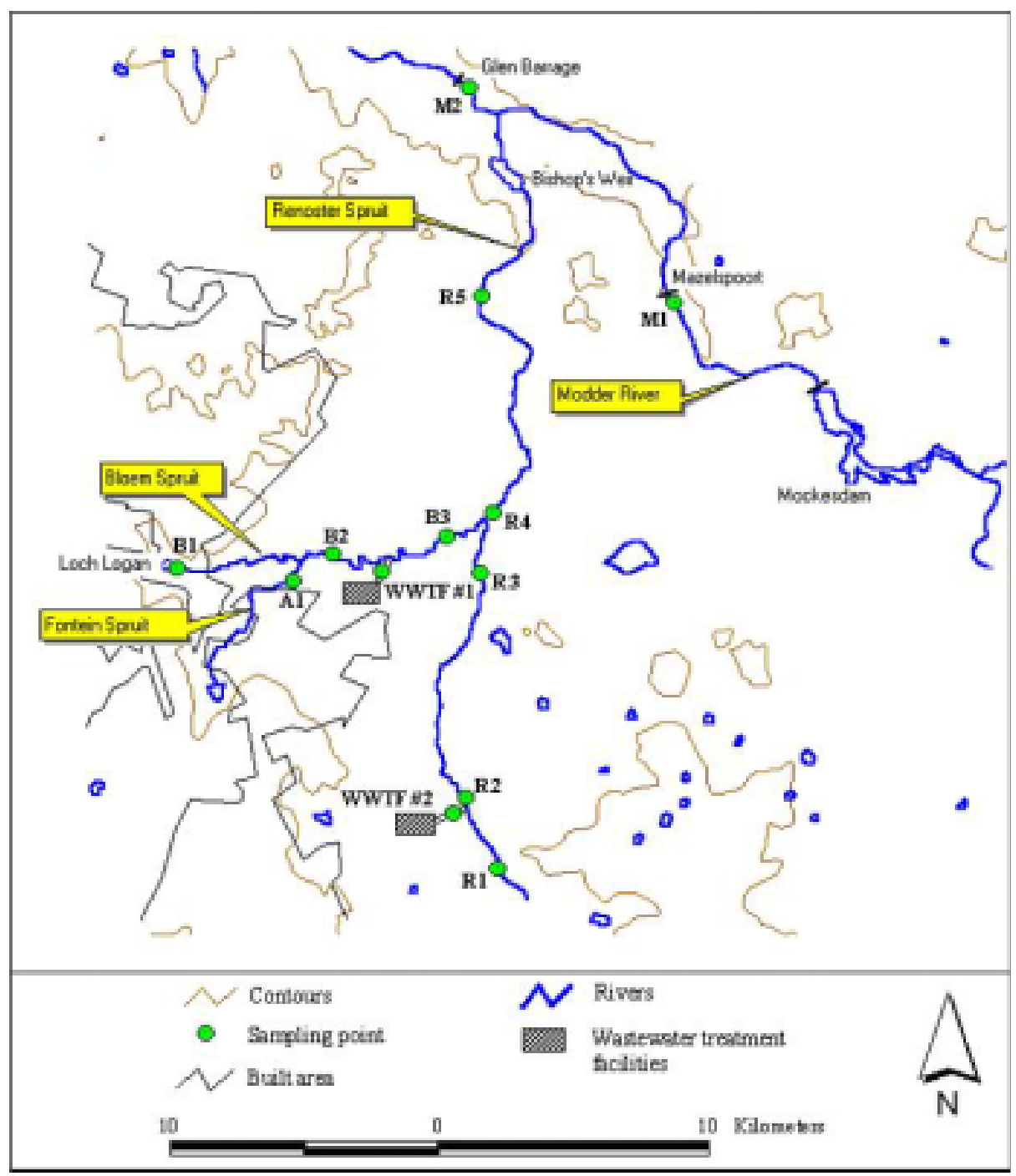

Figure 1

Map indicating the

monitoring sites in the study area of the

Middle Modder

through the greater part of the city and therefore receives the majority of the urban surface water discharges, which are then discharged into the Renoster Spruit.

\section{The city}

Bloemfontein City has established modern, economical and subeconomical residential areas around well-functioning business sectors and well-developed industrial zones. These areas are all serviced by water-borne sewer systems. The city expands into areas of low-cost sub-economical residential settlements also serviced by water-borne sewerage systems. Substantial areas of informal settlement intersperse and fringe the sub-economical residential areas. Sanitation services in these areas generally comprise poorly maintained bucket and traditional unimproved pit latrine systems.

\section{Monitoring sites (Fig. 1)}

\section{Bloem Spruit}

This stream receives:

- Diffuse urban runoff from Bloemfontein City, population approximately 350000 people living in areas serviced by water-borne sewer systems as well as areas with limited or inadequate sanitation systems.

- Wastewater effluents from a well-established wastewater treatment facility (WWTF\#1).

Monitoring Site B1 was situated at Loch Logan, a small impoundment in the Bloem Spruit close to the city centre. The site is surrounded by a waterfront-type entertainment and leisure time development and is used for intermediate-body contact recreational activities such as canoeing and leisure paddle boating. This point was selected to indicate the contribution of surface runoff to numbers of faecal indicator organisms from a large part of the welldeveloped western residential suburbs upstream of the impoundment, as well as to indicate the possible risk of infection to users of the water. Further downstream of B1, the Bloem Spruit receives runoff from the predominantly commercial, industrial areas of the city, as well as runoff from a minor tributary, the Fontein Spruit.

Monitoring Site A1 was selected in the Fontein Spruit just upstream of confluence with the Bloem Spruit. The Fontein Spruit drains surface runoff from the low-cost high-density and informal residential zones of southeast Bloemfontein into the Bloem Spruit.

Monitoring Site B2 was situated approximately $1.2 \mathrm{~km}$ downstream of the Fontein Spruit confluence and $5 \mathrm{~km}$ downstream from B1. Water sampled at this point was considered representative of the city's diffuse runoff, before receiving final effluent discharges 
from WWTF\#1. Site B3, approximately $800 \mathrm{~m}$ downstream of the effluent discharge point, represented the majority of urban surface water discharges from Bloemfontein City.

\section{Renoster Spruit}

The Spruit receives:

- Final effluent from a wastewater treatment works (WWTF\#2) that, at the time of the study, had been recently commissioned. - Polluted urban discharges from the Bloem Spruit.

Monitoring Site R1 was a considerable distance upstream of the city sphere in an agricultural surrounding, sparsely populated by livestock and humans. Water sampled at this point was considered to represent stream water draining from areas not influenced by urban developments. Results from this point were used to reflect the natural background microbiological quality of surface water in the subcatchment before receiving discharges from the city. The numbers of microbiological indicator organisms in the Bloem, Fontein and Renoster Spruit systems, could therefore be compared to guideline values, as well as the levels of organisms measured at $\mathrm{R} 1$ to get a better idea of the magnitude of the impact of microbiological urban pollution.

Site R2 was selected immediately downstream of the final effluent discharge point from the then newly commissioned WWTF\#2 to determine whether the discharges caused an increase in the faecal indicator organism numbers detected in the Renoster Spruit. Site R3 was immediately upstream of (approximately $300 \mathrm{~m}$ ) the confluence with the Bloem Spruit and represented the residual levels of microbial indicator organisms in the Renoster Spruit before being impacted by the Bloem Spruit. R4 was immediately downstream of the confluence with the Bloem Spruit. The microbiological water quality at this point was considered to reflect the impact of the majority of urban discharges from Bloemfontein City on the numbers of faecal organisms in the Renoster Spruit. R5 was the final downstream monitoring site in the Renoster Spruit. Results of water quality sampled at this site were considered to reflect the capacity of the Renoster Spruit to assimilate the microbiological contaminants from all the various discharges from Bloemfontein before draining into the Modder River.

Monitoring site M1 was the reference point in the Modder River approximately $5 \mathrm{~km}$ upstream of the Renoster Spruit confluence. This site was at a point of extraction of raw water to be treated and distributed for domestic, commercial and industrial supply in Bloemfontein. Water in the area is also used intensively for recreational activities such as water-skiing events. Results obtained at this point reflected the background water quality of the Modder River. Site M2 was selected approximately $300 \mathrm{~m}$ downstream of the confluence with the Renoster Spruit. Results obtained from samples taken at this site reflected the impact the Renoster Spruit might have on the numbers of faecal indicator organisms detected in the Modder River.

The effluents of both the wastewater treatment facilities were also sampled immediately prior to being discharged into their respective receiving water bodies.

\section{Methodology}

\section{Sampling}

Water samples $(500 \mathrm{ml})$ were collected at least biweekly during all seasons. The samples were collected in sterile Whirlpacks ${ }^{\circledR}$, transported at $<10^{\circ} \mathrm{C}$ to the laboratory and analysed within $6 \mathrm{~h}$. For the Bloem and Fontein Spruit systems, sampling was done over a period of 50 months from January 1996 to March 2000. Samples were taken from the Renoster Spruit in two phases over a period of 31 months (August 1997 to March 2000). Phase I ended in December 1999, just before WWTF\#2 was commissioned. This was to determine the background numbers of faecal indicators in the Renoster Spruit at points R1, R2 and R3. No major human activities such as informal residential developments etc., were evident in the catchment area of this section of the Spruit during this sampling period. Sampling for Phase 2 commenced immediately after the treatment facility was put into operation to determine whether the effluent from the facility would have any impact on the microbiological water quality of the Spruit. Sampling at sites R4 and R5 in the Renoster Spruit was done over a period of 50 months from January 1996 to March 2000. WWTF\#1 was sampled from January 1996 to March 2000 and sampling at WWTF\#2 commenced after the treatment facility started in January 1999.

\section{Microbiological indicator organisms}

A suite of microbiological indicator organism groups was used to indicate the potential impact of the discharges on the microbial quality of the receiving water systems. Escherichia coli were used to indicate the presence of bacterial pathogenic organisms in faecally polluted waters (DWAF, 1996a). Clostridium perfringens were used because these bacteria provide a more realistic indication of the presence of resistant pathogens such as cyst- and oocystforming protozoa of faecal origin than E. coli (Payment and Franco, 1993). Somatic coliphages gave a more realistic indication of the possible presence of enteric viruses in water than $E$. coli or C. perfringens (Grabow, 2001).

\section{Assay methods}

The membrane filtration technique (Standard Methods, 1998) was used to determine the numbers of E. coli and C. perfringens. E. coli were enumerated on Chromocult Coliformen Agar (Merck, 1996), with dark blue to violet colonies counted as $E$. coli. Water samples for $C$. perfringens analyses were pasteurised prior to filtration to knock out background flora that might influence the growth of C. perfringens (Jagals, 2000; Ferguson et al., 1996). C. perfringens were enumerated on supplemented Perfringens (OPSP) Agar (Oxoid, 1990) with black and black-centred colonies counted as $C$. perfringens. The numbers of E. coli and C. perfringens were expressed as colony-forming units per $100 \mathrm{ml}\left(\mathrm{cfu} \cdot 100 \mathrm{ml}^{-1}\right)$. Positive colonies were confirmed using API 20E (for E. coli) and Rapid ID 32A (for C. perfringens) (BioMérieux, 1998 and 1994). Somatic coliphages were enumerated by the plaque assay method using the double agar layer technique (Grabow, 2001). Plaques were counted as somatic coliphages and expressed as plaqueforming units per $100 \mathrm{ml}\left(\mathrm{pfu} \cdot 100 \mathrm{ml}^{-1}\right)$.

\section{No-observed-adverse-effect-levels (NOAELs)}

Jagals (2000) had compiled, from national and international guidelines, a site-specific set of NOAELs for the indicator organism groups. These NOAELs are used in similar studies throughout the Modder-Riet River catchment. The numbers of microbiological indicator organisms, detected in the Renoster Spruit subcatchment during this study, were compared to these NOAELs for the various water-uses to indicate the potential microbiological infection risk to consumers. 


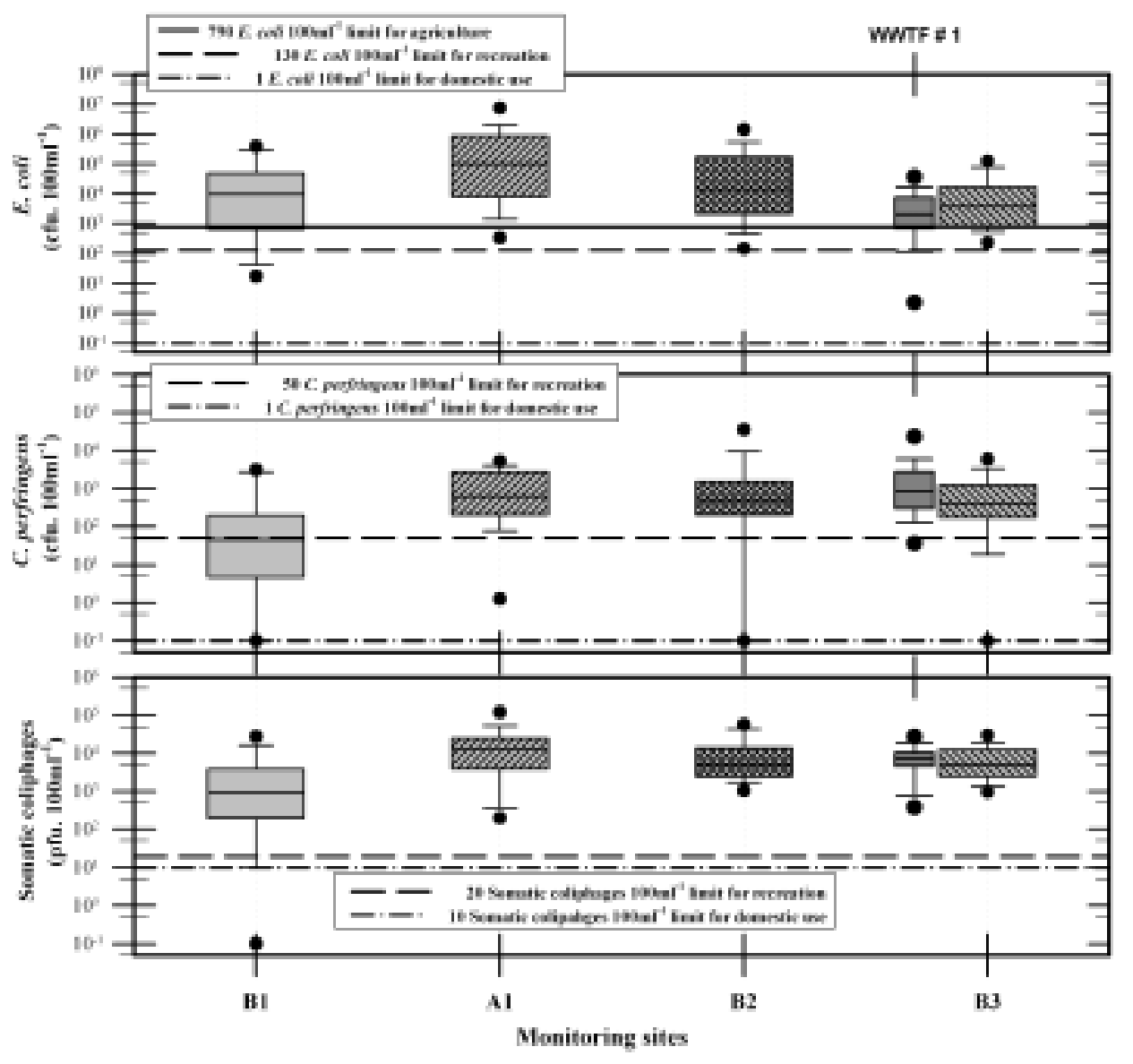

Figure 2

Microbial indicator organism levels detected in the Bloem Spruit system over a period of 50 months

The use of $E$. coli in guidelines has generally been relegated in favour of faecal coliforms because of the historically complex multi-step analysis methodologies required to detect $E$. coli. However, E. coli can now reliably be detected in a single-step procedure (Jagals et al., 2000) and since E. coli is a more reliable indicator of faecal pollution than faecal coliforms (Jagals, 2000; Grabow, 1996), it was decided to use E. coli for this study. Although not common practice, the faecal coliform limits recommended in international as well as local guidelines, were adapted to $E$. coli numbers based on work done by Jagals et al. (2000). Jagals (2000) did not include any NOAELs for somatic coliphages or $C$. perfringens for irrigation of crops that may be eaten raw since it would appear that no such limits have been described as of yet. The following NOAELs were used for this study:

Domestic use: The E. coli and C. perfringens limit within which only an insignificant chance for infection could be expected is $1.00 \mathrm{E}+00 \mathrm{cfu} \cdot 100 \mathrm{ml}^{-1}$. The somatic coliphages limit for a low risk of viral infection is $1.00 \mathrm{E}+01 \mathrm{pfu} \cdot 100 \mathrm{ml}^{-1}$.

Recreational use, particular activities that involved full bodily contact with water: The E. coli limit, below which gastrointestinal effects are not expected, is $1.30 \mathrm{E}+02 \mathrm{cfu} \cdot 100 \mathrm{ml}^{-1}$; for $C$. perfringens the maximum limit for insignificant risk of infection with water consumption is $5.0 \mathrm{E}+01 \mathrm{cfu} \cdot 100 \mathrm{ml}^{-1}$ and for somatic coliphages the limit for a low risk of enteric virus infection is $2.00 \mathrm{E}+01 \mathrm{pfu} \cdot 100 \mathrm{ml}^{-1}$.
Agricultural use: The faecal coliform infection risk limit of $1.00 \mathrm{E}+03 \mathrm{cfu} \cdot 100 \mathrm{ml}^{-1}$ in the WHO (1989) guideline was, for the purposes of this study, adapted to $7.90 \mathrm{E}+02 \mathrm{cfu} \cdot 100 \mathrm{ml}^{-1} E$. coli after the work done by Jagals et al. (2000). No NOAEL is proposed for $C$. perfringens. The faecal coliform guideline approach of Shuval et al. (1997) was used for a NOAEL for enteric viruses. A faecal coliform limit of $1.00 \mathrm{E}+03 \mathrm{cfu} \cdot 100 \mathrm{ml}^{-1}$ was therefore proposed for enteric viruses in waters used to irrigate crops eaten raw.

\section{Statistical analyses}

Data were described statistically for the sample size, geometric mean, median and $95 \%$ confidence intervals, analysed for normality and variance between data groups using the non-parametric MannWhitney Rank-sum and Kruskal-Wallis tests for analyses of variance. In instances where variations between more than two data groups showed significant differences, the Dunn multiplecomparison test (MCT) procedure was used to identify the groups that differed significantly from the others $\left(\operatorname{SigmaStat}^{\circledR} 2,1997\right.$; Helsel and Hirsch, 1995). The data were displayed in line graphs with error bars $\left(5^{\text {th }}\right.$ and $95^{\text {th }}$ percentiles $)$ for spatial appraisal, and in boxplots for statistical appraisal. The $5^{\text {th }}$ and $95^{\text {th }}$ percentiles are indicated with error bars as well as black-dotted end-points (SigmaPlot ${ }^{\circledR}$ 7, 2001). The various dashed lines in each graph indicate the respective NOAELs for domestic, recreational and agricultural uses. 


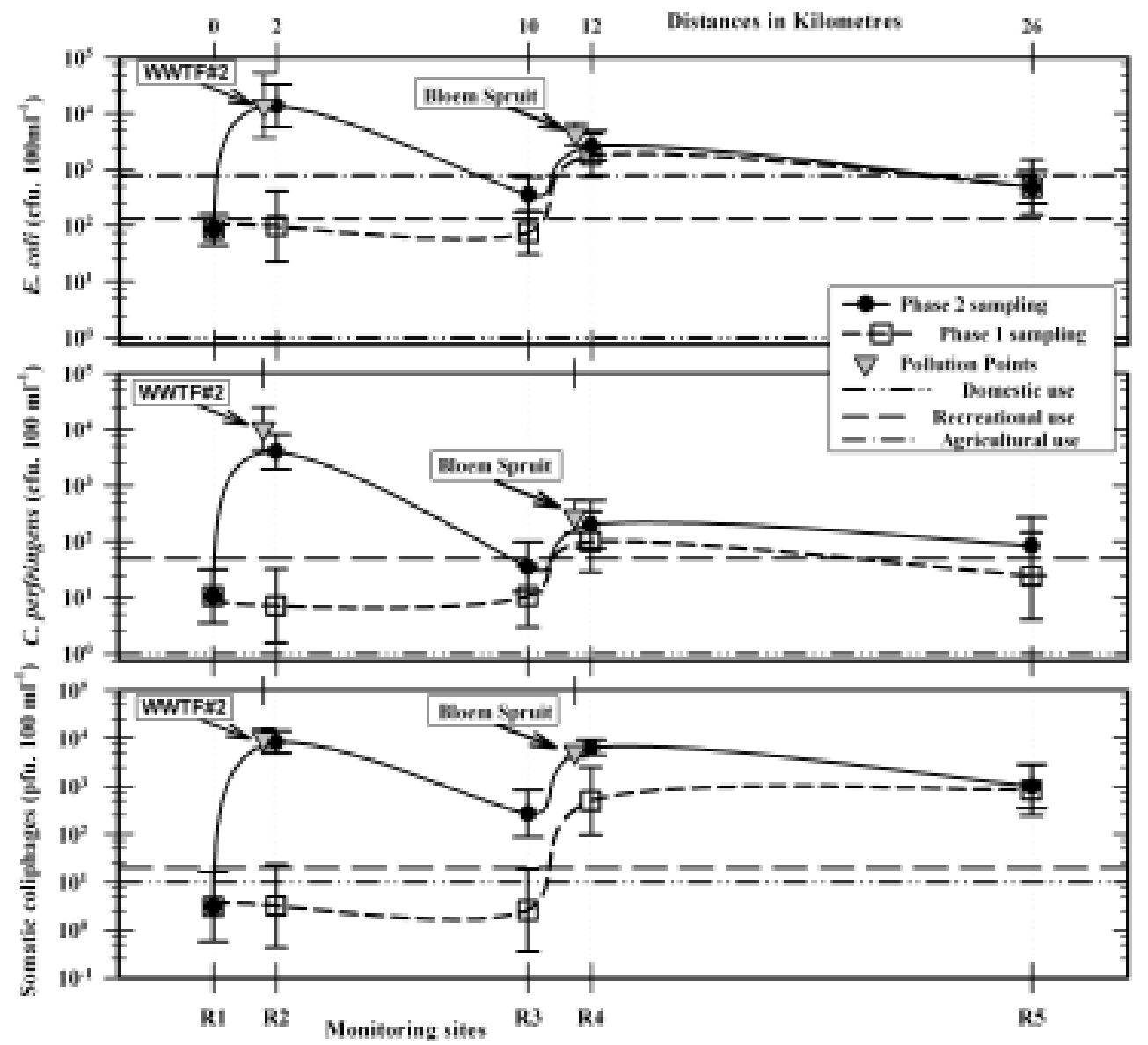

Figure 3

The contibution of urban discharges from Bloemfontein City to microbial indicator numbers in the Renoster Spruit

\section{Results and discussion}

\section{Microbiological quality of water in the Bloem and Fontein Spruit systems and implications for human water users}

At Site B1 in the Bloem Spruit, receiving surface runoff from modern western-style residential suburbs, geometric mean levels of $4.87 \mathrm{E}+03,2.50 \mathrm{E}+01$ and $5.16 \mathrm{E}+02$ per $100 \mathrm{ml}$ for E. coli, $C$. perfringens and somatic coliphages were recorded respectively. These geometric mean levels exceeded all the NOAELs sited by Jagals (2000) for the various uses of water. High numbers of faecal pollution indicators such as these from well-developed urban areas are not uncommon (Jagals, 1994; Geldreich, 1976). A major faecal pollution problem in these areas in this study appeared to be homeless (street) children living under the enclosed sections of the canals using the stream for toilet purposes.

Geometric mean levels of 5.90E+04, 4.02E+02 and 9.10E+03 per $100 \mathrm{ml}$ for E. coli, C. perfringens and somatic coliphages, recorded at A1 in the Fontein Spruit, draining surface runoff from the surrounding low-cost, high-density residential and informal sectors of Bloemfontein, were substantially higher than those at $\mathrm{B} 1$. The numbers of indicator organisms determined at $\mathrm{A} 1$ exceeded the NOAELs recommended for all the various water uses.

At B2, geometric mean levels of $1.51 \mathrm{E}+04,2.78 \mathrm{E}+02$ and $6.34 \mathrm{E}+03$ per $100 \mathrm{ml}$ for E. coli, C. perfringens and somatic coliphages, indicated that the compounded impact of the B1 and A1 discharges exceeded the NOAELs for domestic, recreational and agricultural purposes.

The geometric mean levels at B1, A1 and B2 were higher than the faecal coliform ranges between $1.00 \mathrm{E}+02$ and $2.80 \mathrm{E}+03$ per $100 \mathrm{ml}$, detected downstream from an informal settlement in Gauteng (Grabow et al., 1996), but are similar to those reported for studies done in this area by Köning (1999) and Jagals (1997); by Kienzle et al. (1997) in the KwaZulu-Natal area; and in the Western Cape by Wright et al. (1993). All the results showed that runoff from both developed and developing urban settlements constituted a major source of faecal pollution, with the higher level of pollution emanating from the lesser-developed residential areas.

The E. coli numbers released with the final effluent from WWTF\#1 generally exceeded the faecal coliform standard of $0.00 \mathrm{E}+00 \mathrm{cfu} \cdot 100 \mathrm{ml}^{-1}$ (often relaxed to $1.00 \mathrm{E}+03 \mathrm{cfu} \cdot 100 \mathrm{ml}^{-1}$ in DWAF permits granted for reuse) required in the General Standard in Requirements for the purification of waste water or effluent (Republic of South Africa, 1984). Nevertheless, the E. coli numbers released in the effluent were generally at least one log phase lower than those detected in the water of the Bloem Spruit at B2. C. perfringens and somatic coliphage levels were also above the NOAELs recommended for the water use categories as shown in Fig. 2. This implied that runoff from the city was of a poorer microbiological quality than the quality of effluent from this treatment facility that did not appear to have the capacity to maintain effluent of a microbiological quality below human health impact recommended in the General Standard in Requirements for 
the purification of waste water or effluent (Republic of South Africa, 1984).

The geometric mean indicator organism levels of $4.28 \mathrm{E}+03$ (E. coli), 2.82E+02 (C. perfringens) and 5.27E+03 (somatic coliphages) per $100 \mathrm{ml}$, measured at $\mathrm{B} 3$, were indications of the microbiological water quality of the majority of urban surface discharges from Bloemfontein City. These qualities all exceeded the NOAELs proposed for all the water use categories. Upstream from B3, the water from the Fontein Spruit (as measured at A1) substantially elevated the numbers of indicator organisms in the Bloem Spruit. These levels were then maintained by the numbers of indicator organisms in the effluent discharged from WWTF\#1. Downstream of this point, the Bloem Spruit discharged its high levels of faecal indicator organisms into the Renoster Spruit.

\section{Microbiological quality of water in the Renoster Spruit and implications for human water users}

The background numbers of faecal indicator organisms of water sampled at R1, R2 and R3 are shown in Fig. 3 as the Phase 1 data. There were no significant differences in the water quality sampled at the three sites during this phase (for E. coli $P=0.189$; C. perfringens $P=0.859$; somatic coliphages $P=0.989$ ). This implied that the faecal indicator organism numbers varied little in their natural background state before the commissioning of WWTF\#2.

Although the geometric mean $E$. coli numbers exceeded the NOAEL for domestic use (Fig. 3), water in the Renoster Spruit could, at this stage, be used for domestic purposes with home treatment. The water contained $E$. coli in numbers below the converted faecal coliform level of $2.0 \mathrm{E}+02 \mathrm{cfu} \cdot 100 \mathrm{ml}^{-1}$ reported by Venter et al. (1996) to be a raw water quality suitable for treatment for domestic use. However, the geometric mean levels for $C$. perfringens at these points also exceeded the NOAEL for domestic purposes. This was an indication that riparian users should use a high-energy home treatment method such as boiling to treat this stream-water since disinfection with chlorine-based products would generally not inactivate pathogenic spores.

Land use in this part of the Renoster Spruit is generally characterised by small-scale riparian agriculture. Since a faecal coliform NOAEL of $1.00 \mathrm{E}+03 \mathrm{cfu} .100 \mathrm{ml}^{-1}$ can be used for both a bacterial and viral infection risk limit (Blumenthal et al., 1999; Shuval et al., 1997; Westcot, 1997), the E. coli numbers indicated that the water at this stage was safe to use for agricultural applications, especially for irrigating crops to be consumed raw. A risk of infection for full-body contact recreation was not indicated by any of the three indicator organism groups (Fig. 3).

As with WWTF\#1, the E. coli numbers in the final effluent of WWTF\#2 generally exceeded the faecal coliform standard stipulated in the General Standard in Requirements for the purification of waste water or effluent (Republic of South Africa, 1984) for the duration of the study. Since its commencement stage, the treatment facility did not appear to reduce the numbers of indicator organisms in the raw sewage it received. The NOAELs for agricultural use were also exceeded (Fig.3).

The effluent would, therefore, not be suitable for irrigation reuse on crops that could be eaten raw should its reuse for such purposes be required, e.g. for the irrigation of community gardens. Furthermore, it is questionable whether the potential environmental health impact, that could be caused by the effluent should the system fail to reduce the numbers of faecal indicator organism numbers to below the recommended NOAELs, was considered during the design and operation of the treatment system.
The numbers of microbiological indicator organisms detected at R2 and R3 after the commissioning of WWTF \#2, are shown in Fig. 3 as the Phase 2 results. The increase in the numbers of the three indicator groups is significant at $\mathrm{R} 2(P=<0.001$ for $E$. coli, $C$. perfringens and somatic coliphages) and R3 (for $E$. coli $P=$ $<0.001$; $C$. perfringens $P=0.042$; somatic coliphages $P=0.002$ ). After discharge commenced, the effluent had such an impact on the water in this sector of the Renoster Spruit that it became totally unsuitable for the particular domestic, recreational as well as agricultural uses discussed in this study.

The water quality improved somewhat downstream of R2 towards R3, which is an indication of the assimilative capacity that exists in the Renoster Spruit to reduce the numbers of microorganisms. However, based on the E. coli numbers indicated in Fig. 3 , this improvement was only to the extent that the water became generally safe to use for crop irrigation in the vicinity of R3. The microbiological quality indicated for the other two uses downstream of WWTF\#1, remained above their respective NOAELs.

The results of this part of the study indicated that the newly commissioned wastewater treatment facility had a negative impact on the quality of water in the Renoster Spruit. Faecal indicator organism numbers increased and the water that could previously (Phase 1) be used for recreation and agricultural uses were rendered totally unsafe for all the water use categories at least for the duration of the study.

Results, illustrated in Fig. 3 showed that although effluent from WWTF\#2 had an impact on the numbers of indicator organisms detected in the Renoster Spruit at R2 and R3, the increase in the indicator organism numbers had no influence on the already excessive indicator densities at R4. The data for the indicator organism numbers at R3, B3 and R4 since WWTF\#2 was commissioned, were compared to determine whether the discharge from WWTF\#2 created an additional increase in faecal indicator numbers over and above the increase in indicator organism numbers already caused by the Bloem Spruit. Statistical analyses with the Kruskal-Wallis ANOVA of Ranks showed statistically significant differences $(P=0.001$ for $E$. coli, $C$. perfringens and somatic coliphages) between the data sets, but it was not clear which data set(s) differed from the other(s). To identify the set(s), all three data sets were compared with the Dunn MCT procedure. All three indicator groups at R3 differed significantly $(P=<0.05$ for $E$. coli, $C$. perfringens and somatic coliphages) from those determined at B3 and R4, the latter two showing no significant differences.

According to these results, it can be concluded that although the level of faecal pollution in the section of the Renoster Spruit in which R2 and R3 were located, increased since receiving polluted discharges from WWTF\#2, these increases had no influence on the indicator levels at R4. This is because the main impact in terms of the numbers of faecal indicator organisms at R4 was coming from the Bloem Spruit.

The quality of the water in the Renoster Spruit improved downstream between R4 and R5 (Fig. 3). The geometric mean $E$. coli level measured at R5 was within the NOAEL for agricultural use. The water remained unfit for domestic, recreation as well as for treatment for domestic purpose uses.

The assimilative mechanisms in the sector of the Renoster Spruit from R2 to R3 appeared to be more effective in reducing the micro-organism numbers than the longer sector from R4 to R5, especially for $C$. perfringens and somatic coliphages. As $C$. perfringens and somatic coliphages are more resistant to adverse conditions in environmental waters (Payment and Franco, 1993), the slower reduction in the section of the Renoster Spruit from R4 to R5 is probably due to a build-up from the high levels of faecal 
pollution constantly being discharged by the Bloem Spruit over a longer period of time.

\section{Microbiological quality of water in the Modder River and implications for human water users}

The water at sampling Site M1, upstream of the confluence with the Renoster Spruit, could be extracted and treated for domestic purposes, while the NOAELs for recreation and agricultural uses were also not exceeded with geometric mean levels of $2.00 \mathrm{E}+01$ (E. coli), 4.00E +00 (C. perfringens) and $0.00 \mathrm{E}+00$ (somatic coliphages) per $100 \mathrm{ml}$.

To determine if the Renoster Spruit (R5) had an impact on the quality of water in the Modder River, the water quality at M1 was compared to the quality at M2 and R5. Results indicated that the data of all three groups differed significantly $(P=0.001)$. To identify the data sets(s), that differed, all three data sets were compared with the Dunn MCT procedure. All three indicator organism groups at $\mathrm{R} 5$ differed significantly $(\mathrm{P}=<0.05)$ from those at M1 and M2. The latter two sampling points showed no statistically significant differences. It can therefore be concluded that although the level of faecal pollution in the Modder River increased after receiving the polluted water of the Renoster Spruit, these increases did not cause statistically significant differences in the indicator organism levels at M1 and M2. It would appear that the section of the Renoster Spruit from R5 to the confluence, as well as the larger water mass in the Modder River, could more successfully assimilate the faecal indicator numbers than the section upstream from R5 in the Renoster Spruit during the time of the study.

\section{Conclusion}

Results from this study showed that the water quality in the tributaries of the study sector of the Modder River generally exceeded microbiological infection risk limits proposed in water quality guidelines for domestic water use, recreation, and irrigation of crops eaten uncooked. This is due to polluted surface water runoff from the city, as well as discharges from the two wastewater treatment facilities. While it appears, for the moment, that the Modder River could successfully negate the impact, the rapid rate of urbanisation currently experienced in the area, could increase pollution from urban sources, thus intensifying the negative impact beyond the assimilative capacity of the river. This could have a negative impact on the health of people, depending on the use of the water from the river. Effective catchment management, with a strong focus on public health protection, should be implemented as a matter of urgency.

\section{Acknowledgements}

The assistance of the Foundation for Research Development, Technikon Free State and the University of Pretoria is gratefully acknowledged.

\section{References}

BIOMÉRIEUX (1994) Rapid ID 32 A - Identification system for anaerobes. Catalogue No. 07881 A - 08/94.

BIOMÉRIEUX (1998) API 20 E - Identification system for Enterobacteriaceae and other Gram - negative rods. Catalogue No. 07584 B $-04 / 98$.

BLUMENTHAL U, PEASEY A, RUIZ-PALACIOS G and MARA DD (1999) Guidelines for wastewater reuse in agriculture and aquaculture: recommended revisions based on new research evidence. Water and Environ Health at London and Loughborough. Task No. 68, Part 1.
CHAPRA SC (1997) Surface Water-Quality Modelling. McGraw-Hill, New York.

DEPARTMENT OF WATER AFFAIRS AND FORESTRY (DWAF) (1995) Procedures to Assess Effluent Discharge Impacts. South African Water Quality Management Series ( $1^{\text {st }}$ edn.). Water Research Commission. WRC Report No. TT 64/94. Pretoria.

DEPARTMENT OF WATER AFFAIRS AND FORESTRY (1996a) South African Water Quality Guidelines. Vol. 1 (Domestic Use). Pretoria.

DEPARTMENT OF WATER AFFAIRS AND FORESTRY (1996b) South African Water Quality Guidelines. Vol. 2 (Recreational Use). Pretoria.

FERGUSON CM, COOTE BG, ASHBOLT NJ and STEVENSON IM (1996) Relationships between indicators, pathogens and water quality in an estuarine system. Water Res. 30 (9) 2045 - 2054.

GELDREICH EE (1976) Faecal coliform and faecal streptococcus density relationships in waste discharges and receiving waters. CRC Critical Reviews on Environmental Control. 349 - 369.

GRABOW WOK (1996) Waterborne diseases: Update on water quality assessment and control. Water SA 22 (2) 193 - 202.

GRABOW WOK (2001) Bacteriophages: Update on application as modes for viruses in water. Water SA 27 (2) 251 - 268.

GRABOW WOK, TAYLOR MB and WOLFAARDT M (1996) Research on Human Viruses in Diffuse Effluents and Related Water Environments. Water Research Commission. WRC Report No. 496/1/96. Pretoria.

GRIESEL M (2001) The Effect of Various Urban Discharges on the Microbiological Water Quality in Catchment Systems: An Environmental Health-Related Impact Study. M.Tech. Dissertation, Technikon Free State, Bloemfontein.

HELSEL DR and HIRSCH RM (1995) Statistical Methods in Water Resources. Elsevier, Amsterdam.

JAGALS P (1994) The Effects of diffuse effluents from Botshabelo on the microbiological quality of water in the Modder River. M.Dip. Public Health Dissertation. Technikon Free State, Bloemfontein.

JAGALS P(1997) Stormwater runoff from typical developed and developing South African urban developments: Definitely not for swimming. Water Sci. \& Technol. 35(11-12) 133 - 140.

JAGALS P (2000) The impacts of polluted urban runoff on the Modder River catchment: a microbiological perspective. D.Tech. Thesis. Technikon Free State, Bloemfontein.

JAGALS P, GRABOW WOK, GRIESEL M and JAGALS C (2000) Evaluation of selected membrane filtration and most probable number methods for the enumeration of faecal coliforms, Escherichia coli and enterococci in environmental waters. Quantitative Microbiol. 2 (2) (June) 129 - 140.

KIENZLE SW, LORENTZ SA and SCHULZE RE (1997) Hydrology and Water Quality of the Mgeni Catchment. Department of Agricultural Engineering, University of Natal, Pietermaritzburg. Water Research Commission. WRC Report No. TT87/97. ACRU Report 45/97.

KINDZIERZKI WB and JACKSON LG (1998) Evaluation of Canadian drinking water guidelines using probability modelling of population exposure. Water Sci. Technol. 38 (6) 229 - 236.

KOLLURU R, BARTELLS, PITBLADO R and STRICOFF S (1996) Risk Assessment and Management Handbook for Environmental, Health, and Safety Professionals. McGraw-Hill Inc. New York.

KÖNING N (1999) Water Quality of the Modder River. M.Sc. Dissertation, Univ. of the Free State, Bloemfontein.

MERCK CORPORATION (1996) Coliforms Show Their True Colours. Catalogue. No. 1.10426. Merck KgaA, 64271 Darmstadt, Germany.

OXOID CORPORATION (1990) The Oxoid Manual (6 $6^{\text {th }}$ edn.). Bridson, EY (ed). Basingstoke, UK.

PAYMENT P and FRANCOE (1993) Clostridium perfringens and somatic coliphages as indicators of the efficiency of drinking water treatment for viruses and protozoan cysts. Appl. Environ. Microbiol. 59 (8) 2418 $-2424$.

REPUBLIC OF SOUTH AFRICA (1984) Requirements for the purification of waste water or effluent. Department of Water Affairs and Forestry. Government Gazette: 14 February 1984.

SHUVAL H, LAMPERT Y and FATTAL B (1997) Development of a risk assessment approach for evaluating wastewater reuse standards for agriculture. Water Sci. Technol. 35 (112) 15 - 20. 
SIGMAPLOT $^{\circledR} 7$ (2001) Exact Graphs for Exact Science: Users Manual. SPSS Science Inc. Chicago.

SIGMASTAT ${ }^{\circledR} 2$ (1997) Statistical Software: Users Manual. SPSS Science Inc. Chicago.

STANDARD METHODS (1998) Standard Methods for the Examination of Water and Wastewater. $\left(20^{\text {th }}\right.$ edn.). Andrew D Eaton, Lenore S Clesceri and ArnoldE Greenberg. American Public Health Association, Washington DC.

VENTER SN, STEYNBERG MC, DU PLESSIS G, DE WET CME, HOHLS D, RODDA N and KFIR R (1996) Tools for Microbiological Water Quality Assessment of South African Rivers. Report to the
WRC. Division of Water, Environment and Forestry Technology with Rand Water. WRC Report No. 380/1/96. Pretoria.

WESTCOT DW (1997) Quality Control of Wastewater for Irrigated Crop Production. Water Report No. 10 FAO, Rome.

WORLD HEALTH ORGANISATION (WHO) SCIENTIFIC GROUP (1989) Health Guidelines for the Use of Wastewater in Agriculture and Aquaculture. Technical Report Series No. 778. Geneva.

WRIGHT A, KLOPPERS W and FRICKE A (1993) A hydrological Investigation of the Storm Water Runoff from the Khayelitsha Urban Catchment in the False Bay Area, South Western Cape. Water Research Commission. WRC Report No. 323/1/93. 